IT has been claimed on a number of occasions during the past few years that it is possible to bring about substantial improvements in the health and well being of the poor people of the world by the application of some relatively cheap and simple technology. Such a possibility seems theoretically doubtful and we feel that it is most important that attention should not be distracted from the real problems of social and economic developments by exaggerated claims for the impact of some particular technique. It is for this reason that Aaron Altschul's restatement of the apparent benefits of fortification of foods with amino acids ${ }^{1}$ needs a critical appraisal.

We might begin by pointing out the significant fact that although the advantages of adding amino acids to human foods have been vigorously promoted for at least 20 years, and the technology for doing so has been available for as long, there is to date not a single example of a controlled field trial on a population basis which has shown any measurable benefit to man. We believe there are both nutritional and logistic reasons for this.

The nutritional basis for amino acid fortification rests upon the proposition that a specific deficiency of protein is a common cause of ill health. Such a statement requires definition. It is important to distinguish between the physiological needs for protein as a nutrient and the desire for foods such as meat, milk, eggs and fish. It has been a consistent feature of the arguments of those who advocate protein or amino acid fortification as a cure for malnutrition that they confuse the problem of meeting physiological needs for protein with the problem of meeting demands for aesthetically satisfying diets. Perhaps it is not surprising that many people can see no way in which the demands of the rich for meat could (or even should) be moderated in the light of the needs of the poor for bread. It is surely hypocrisy to pretend on the one hand that these demands

\section{Strategy for a hungry world}

Dr D. S. Miller of Queen Elizabeth College, and Dr P. R. Payne of the London School of Hygiene and Tropical Medicine take issue with a recent article in Nature on the value of amino acid supplementation, especially in developing countries.

and needs are both expressions of the same protein problem, and on the other to suggest that the needs of the poor can be satisfied by fortification of staple foods with a tasteless, odourless powder which will help neither to satisfy hunger or incidentally to improve the nutritive value of the diet.

The second problem of definition is to distinguish between diets which are 'limited' by a particular amino acid and those which are 'deficient'. For example the traditional English breakfast of porridge, bacon and eggs, toast and coffee contains a protein mixture that if fed under carefully controlled conditions could be shown to be limited by methionine. But this is neither evidence that the UK population is at risk from methionine or protein deficiency, nor does it justify the fortification of breakfast foods with amino acids. A diet may only be considered deficient in an amino acid if it contains less than the requirements of the consumer.

Dr Altschul correctly points out that standards of protein requirements are now "lower than before". What he does not point out is that one takes the latest FAO/WHO standards ${ }^{2}$, it can be shown that the required percentage of calories from protein in mixed diets as eaten by man is only $8 \%$. This assumes that the efficiency of protein utilisation of human diets eaten in poor countries is about $65 \%$. In fact, the calculated efficiency derived from the methods given by the $\mathrm{FAO} / \mathrm{WHO}$ report is higher than this at about $90 \%$ which would lower the required percentage of dietary protein even more. Thus the cited projection that the protein content of the diets eaten in South Asia will fall from $10.2 \%$ to $9.8 \%$ by 1980 does not indicate impending disaster. Of course there are those who argue that the poorest people are eating bread or rice alone. These cereals will have an efficiency of utilisation about $50 \%$, and hence the required protein content of the diet would rise to $10 \%$, still covered by cereals alone. Another argument is that cereals do not contain enough protein for the vulnerable groups in the population such as preschool children. But the latest requirements indicate that they also require only $10 \%$ cereal protein as a percentage of the calories. Thus simple protein deficiency cannot occur in areas where cereals are the cheapest food, and amino acid supplementation would therefore be a wasted effort. Simple protein deficiency can only occur where the staple food contains less than $10 \%$ protein such as cassava, sago, and plantain. Since these foods contain virtually no protein, supplementation with a few amino acids cannot increase their useful protein content by changing protein quality.

This is not to say that there is no such thing as protein-calorie malnutrition. This syndrome arises chiefly because children do not eat enough food. It is complicated by disease, especially diarrhoea, respiratory infections and measles, but the prime cause is insufficient food. We were interested to read in the same issue of Nature, the account by Ethiopian relief workers and their critical assessment of protein-rich foods. Indeed your editorial correctly praised this group for their design of an energy-rich food for use in such situations. It is clearly non-

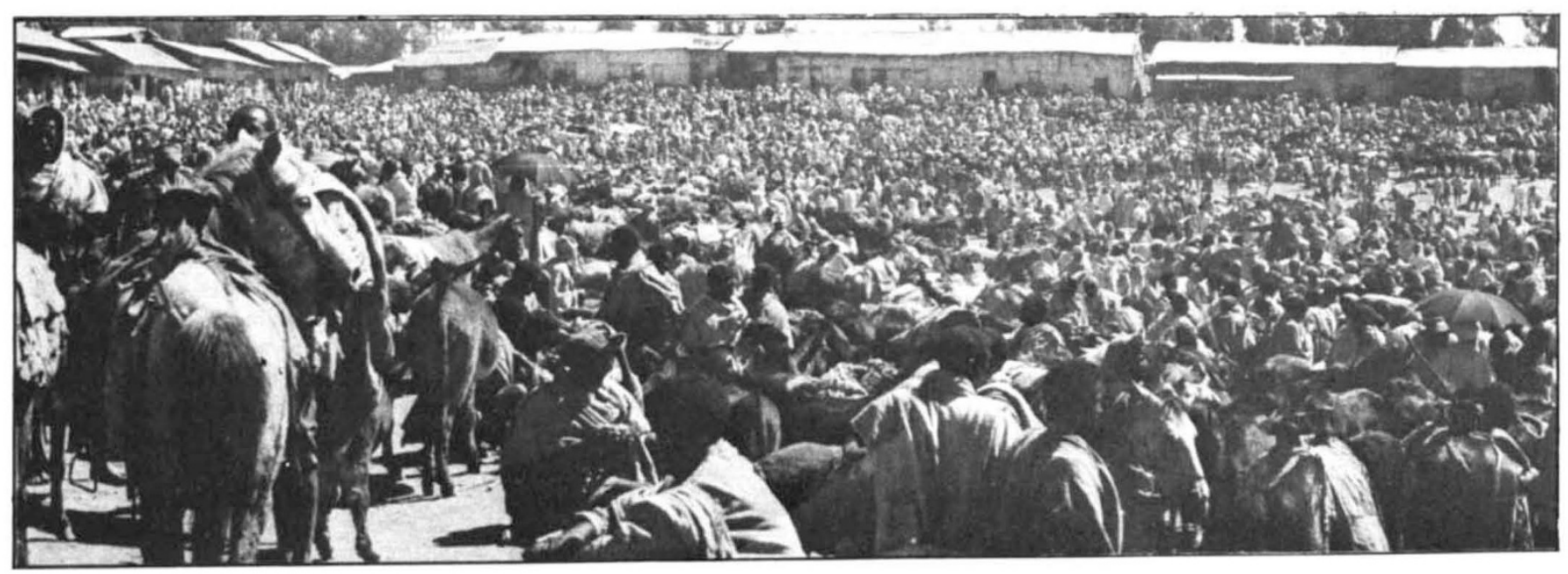


sense to supply developing countries with single nutrients, such as amino acids or vitamins, when some people are unable to buy and consume enough of the traditional diet which has sustained the population for centuries.

Turning now to the logistic problems of amino acid fortification, we would suggest the following conditions before any project should be implemented.

- That the limiting amino acid in the diet as distinct from the staple food, must be known. The extent of the limitation must also be known. In practice, cereal-bascd diets as eaten are found not to be limited by lysine. Miller and Donoso ${ }^{3}$ have shown that the limiting amino acid of most dicts, including cereal diets, is methionine. Also that the improvement in the effective protein content when methionine is added is trivial in comparison with the data cited by $\mathrm{Dr}$ Altschul concerning the effect of the addition of lysine to flour alone.

- That the supplemented food is consumed by the vulnerable groups in the population. This is normally only practicable where the staple foods are centrally processed and almost impossible where the major proportion of the population are subsistence farmers.

- That the project is the cheapest method of improving the diet as a whole. Since the chief cause of malnutrition is poverty, amino acid supplementation should be regarded by governments as an alternative to raising the standard of living. Thus to compare a scheme for adding lysine to wheat with one for improving milk production from marginal grassland, purely on the basis of the yield of protein is misleading. Improving agriculture provides employment, can be achieved within the country, and produces a product which is both aesthetically satisfying and acceptable. Fin- ally we must point out that $\mathrm{Dr}$ A]tschul does not fully quote one of his references ${ }^{4}$, which indicates that the cost of fortification of all cereals in India would be no less than 16\% of the Central Government Budget, or approximately five times the money spent on health.

We conclude that amino-acid fortification of staple foods should be rejected on nutritional and logistic grounds. The best solution to the problem of malnutrition is to raise the standard of living and to improve traditional agriculture. Aid to the subsistence farmers is the best way to achieve both.

\footnotetext{
1 Altshul, A. M., Nature 248, 643 (1974).

${ }^{2}$ FAO/WHO Technical Report No. 522 (1973).

${ }^{3}$ Miller, D. S., and Donoso, G., J. Sci. Fd. Agric., 14, 345 (1963).
}

${ }^{4}$ Schertz, L. P., Nutr. Rev., 31, 293 (1973).

\section{international news}

THE World Health Organisation (WHO) has been carrying out allegedly secret research projects in India, financed by agencies of the U.S. government. It has recently come to light that the U.S. Army has been an interested recipient of the research results from these projects.

The WHO experiments are being conducted (some have been completed) at the Genetic Control of Mosquito Unit (GCMU) in New Delhi, Bombay Natural History Society (BNHS) and the malaria eradication station in Jodhpur (Rajasthan state). The projects in question relate to the genetic control of mosquitoes, bird migration and the like-seemingly scientific investigations, till one takes a closer look at the related details. But Indian experts feel that the experiments could also provide data on the availability, bchaviour and peculiarities of disease carriers in India-information that could be of value in biological or germ warfare.

Until recently the GCMU had been collecting data on the ecology, behaviour and dispersal patterns of mosquitoes in South Delhi and in Faridabad, a sprawling industrial complex near the capital. Some scientists have expressed fear that, using these data, an enemy could conceivably employ mosquitoes for the effective transmission of germs and viruses. Also, the GCMU conducts most of its experiments in and around Delhi-an area known not to be endemic for malaria or filariasis-instead of in the really

\section{Doubts over US in India}

from Narender $K$. Sehgal

endemic areas around the country.

The GCMU proposes to launch a big experiment early next year in Sonepat (again near Delhi) aimed at genetic control of aedes aegypti-in spite of the fact that the GCMU's first priorities ought to be malaria and filariasis carriers. Malaria is back in India and filariasis is endemic in an area occupied by a fourth of the Indian population. Dengue, unknown in India before July 1963 when it was detected for the first time in Calcutta, appears sporadically. Yellow fever is nonexistent in India, not a single case having been reported in ages. This, it is argued, may be because of some 'balancing virus' that ensures protection against this disease. But the GCMU's genetic experiments could reduce or destroy this natural 'balance' and render the country vulnerable to yellow fever.

Indian scientists taking part in the GCMU's projects point out that their project leaders are, and have been in the past, U.S. government scientists. Two years ago, the GCMU attracted public attention when it was found to have been polluting village wells- apparently in the course of scientific experiments-with chemicals suspected to be cancer-causing and prohibited in the USA. Since then secrecy around GCMU projects has been reportedly tightened.

Another controversy that has been raging among the scientific community here has to do with the role of Indian scientists and research organisations in programmes sponsored jointly by the Migratory Animal Pathological Survey (MAPS) of the U.S. Armed Forces Institute of Pathology and WHO. Reacting to criticism in the Indian Parliament the president of the Bombay Natural History Society, in a letter to a New Delhi daily, stoutly defended his society's collaboration with the MAPS on bird migration projects; he denied allegations of secrecy, ongoing collaboration arrangements with the MAPS and employment of U.S. personnel in bird migration studies.

Following this a scientist of the Jawaharlal Nehru University in New Delhi, in a letter to the same daily, pointed out a few things the BNHS president forgot to mention in his letter. Namely that (i) the blood samples of the birds caught by the BNHS were not analysed in India but were sent for the purpose to the Smithsonian Institute and the MAPS in the USA; (ii) two American scientists belonging to the Smithsonian were associated with the BNHS-MAPS programmes in India; (iii) the services of the BNHS and VRC (Virus Research 